\title{
Determining Critical Service Attributes and Appropriate Improvement Actions in Indonesian HEIs
}

\author{
Ronald Sukwadi* \\ Department of Industrial Engineering, Atma Jaya Catholic University, Jakarta, Indonesia; \\ Department of Industrial and Systems Engineering, Chung Yuan Christian University, Chung Li, Taiwan \\ Ching-Chow Yang \\ Department of Industrial and Systems Engineering, Chung Yuan Christian University, Chung Li, Taiwan
}

(Received: March 11, 2012 / Revised: May 16, 2012 / Accepted: June 7, 2012)

\begin{abstract}
To gain competitive advantage in a fast changing environment, the higher education institution (HEI) must continuously adjust the strategies to that environment. One important strategy is how to determine appropriate practical actions based on what students really need and want. Despite the abundance of research on service quality management, there is no universal consensus on how best to determine appropriate practical actions in HEIs. The aim of this paper is to develop an integrated model to be used to accurately acquire the most critical service attributes and determine appropriate actions that promote student satisfaction. Drawing on relevant literature, an integrated model is proposed which is based on students' perspective by integrating the fuzzy SERVQUAL, refined Kano, and Blue Ocean model. Subsequently, an empirical case study in the higher education sector is described that illustrates the value of the model in determining the most critical attributes and how to improve them.
\end{abstract}

Keywords: SERVQUAL, Fuzzy, Refined Kano Model, Critical Service Attributes, Appropriate Actions

* Corresponding Author, E-mail: ronald.sukwadi@atmajaya.ac.id

\section{INTRODUCTION}

In the age of growing service industries, providing excellent service quality is increasingly more important. Service quality and customer satisfaction have gradually been recognized as key factors used to gain a competitive advantage. While a multitude of factors may contribute to the decision process, the underlying factor that differentiates itself and taps into the direct experience of the consumer is service quality (Cronin and Taylor, 1992). The provision of excellent services is central to the competitive strategies of most industries, because providing high quality service is an important strategy for business survival and growth (Zeithaml et al., 1996; de Ruyter et al., 1997).

There are many challenges facing every educational institution as a service provider. As such, higher education would be considered a part of the service industry in providing quality learning experiences to students. With the proliferation of study options available to students, it is no wonder that the higher education institutions (HEIs) are under pressure to provide high quality service to students so as to capture the market share (Gapp and Fisher, 2006). Students will have the opportunity to base their continued enrollment with higher educational institutions on how well the education programs and services meet their expectations. Hence, service quality becomes the means for many institutions 
to retain the number of students and to capture the educational market (Yeo, 2008; Brochado, 2009).

The role of service quality in higher education has received increasing attention. Universities have seen the provision of higher education that becomes a product and have been driven by competition to examine the quality of their services, to redefine their product and to measure customer satisfaction in ways that are familiar to service marketing specialists (Kotler and Fox, 1985). Higher education is also being driven towards commercial competition imposed by economic forces resulting from the development of global education markets (Joseph et al., 2005).

In competitive markets, satisfaction with services may make the difference (Zeithaml et al., 1996). Satisfaction may influence a student's desire to attend or leave various higher education institutions. Universities should include a service quality assessment in their efforts to be accountable for the effectiveness of their services (Ham and Hayduk, 2003). Higher educational institutions should also ensure that all services are managed to enhance students' expectations (Hill et al., 2003; Brochado, 2009). Universities have realized that their long-term survival depends on how appropriate and how good their service strategies are (Nasser et al., 2008; Brown and Mazzarol, 2009).

The subject of determining critical attributes and appropriate service strategies is emphasized by several studies. More recently, several researchers have explored the subjects by varying perspectives and using different methodologies. The SERVQUAL has been used to determine critical attributes of various services, and the improvement actions are derived based on a gap score of expectation and perception (Parasuraman et al., 1988). Despite being refined over a period of years $(1988,1991$, and 1994), SERVQUAL still displays a lack of consistency in questionnaire scales that measure service quality. One primary concern is that it departs from the 'static' scales of expectations and/or perceptions. These scales fail to capture the real answer of an individual's evaluative process because attributes measuring service quality are characterized by uncertainty, subjectivity, imprecision and ambiguity (Chien and Tsai, 2000; Benitez et al., 2007; Lin, 2010). In other words, when respondents make decisions, they usually employ subjective knowledge and it remains fuzzy $(\mathrm{Hu}, 2009$; Chien and Tsai, 2000).

The method based on fuzzy numbers makes linguistic terms more objective, and it is different from general research using statistical methods in service quality research. To investigate the population, the respondent's opinions or the complexity of a subjective event more accurately, it is suggested that we had better use the fuzzy logic (Benitez et al., 2007; Lin, 2010). The fuzzy approach simultaneously renders the discretions on the linguistic problems in SERVQUAL questionnaires much more accurately (Chien and Tsai, 2000; Hu, 2009; Lin, 2010). In this paper, we are going to use the fuzzy set theory and apply it in the SERVQUAL questionnaires.

Furthermore, Kano's method is a powerful way to classify categories of quality attributes as customer requirements and is widely used by industries and researchers (Kano et al., 1984). The category results, however, have a deficiency that prevents service providers from precisely evaluating the influences of quality attributes. The weakness is a failure to take into account the degree of importance accorded to certain quality elements by customers, so the Kano model can be refined (Yang, 2005). The refined Kano's model as presented by Yang (2005) further improved the Kano's model to categorize the quality attribute more precisely.

Most strategy formulation techniques and practices focus on eliciting requirements from existing, known customers. However, these techniques and practices aren't sufficient for surviving in current highly competitive markets. The blue ocean strategy (BOS) is used to create a new marketplace value and so make competition irrelevant (Kim and Mauborgne, 2005). A "blue ocean" is a potential market where competition does not yet exist. In contrast, a "red ocean" is a bloody market where companies compete intensely for a share of a limited market space. BOS seeks to remedy this by not only decoding the pattern and principles behind the successful creation of blue oceans, but also by providing the analytical frameworks and tools to act on this insight.

Starting with an integrative framework, the paper outlines the results of a study conducted on higher education to determine the critical service attributes and their appropriate practical actions. For determining the critical service attributes accurately, it is necessary to develop the fuzzy SERVQUAL questionnaires. Here, we induce general solutions to find that the intersections are between two triangular fuzzy numbers, so the discrepancy rate between satisfaction degree (perception and expectation) and importance degree can be evaluated and integrated with a refined Kano model. Finally, four actions framework of the BOS model is applied to determine appropriate improvement actions based on the categories of attributes identified in the refined Kano model.

\section{THEORITICAL REVIEW}

This section aims to identify the theoretical composition that is considered as the objective of this study. Before the development of the integrated model, we first explain the critical methods, which are the essentials of the integrated model.

\subsection{SERVQUAL}

The SERVQUAL method developed by Parasuraman et al. (1985) is a best-known service quality measurement model. They developed a service quality con- 
ceptual model between consumers and firms in some industries, and proposed five gaps in which the fifth is defined as "the quality that a consumer perceives in a service is a function of the magnitude and direction of the gap between expected service and perceived service." In their model, the expected service describes the consumers' expectations about what service a firm should provide and perceived service reveals consumers' feelings about what service delivery consumers actually received from a firm. Based on the service quality gaps, the service provider can determine the service quality improvement plans to improve customer satisfaction. Assessing service quality using SERVQUAL involves computing the difference between perception score and expectation score obtained from the questionnaire survey to the customers (Parasuraman et al., 1985). For each quality attribute, the SERVQUAL score is computed as follows:

$$
\text { SERVQUAL score }=\text { Perception }- \text { Expectation }
$$

When service quality is mentioned, the dimensions (reliability, responsiveness, competence, access, courtesy, communication, credibility, security, understanding, and knowing the customer as well as tangibles) proposed by Parasuraman et al. (1985) come to our mind. Parasuraman et al. (1988) developed a multiple-item scale (SERVQUAL) for measuring service quality and simplified the ten dimensions of service quality to five dimensions. These five dimensions are related to both the service process and its outcome. The SERVQUAL method uses the questionnaire consisting of 22 pairs of quality attributes based around 5 key dimensions (Parasuraman et al., 1988):

1. Tangibles: appearance of physical facilities, equipment, personnel, and communication materials

2. Reliability: ability to perform the promised service dependably and accurately

3. Responsiveness: willingness to help customers and provide prompt service

4. Assurance: knowledge and courtesy of service providers and their ability to convey trust and confidence

5. Empathy: care and individualized attention to its customers provided by the firm

\subsection{Fuzzy Approach}

The fuzzy approach theory was the first breakthrough by an automation professor Zadeh (1965) of the University of California in Berkeley. He used mathematical methodology to present the uncertainty in real life. For instance, in linguistic terms, such as satisfied, fair, and dissatisfied, are usually regarded as natural representations of the customers' preferences or assessment, and more or less represent some degree of uncertainty and vagueness in human thought. This problem will be answered by the use of fuzzy approach in captur- ing the decision makers' preference structure. The fuzzy approach aids in reducing the ambiguity of concepts that are associated with human beings' subjective judgments (Benitez et al., 2007; Lin, 2010). In other word, the fuzzy theory can be used in a performance measurement by objectifying the evaluators' subjective judgments (Lee and Huang, 2009).

A linguistic variable is a variable with linguistic words or sentences in a natural language. The performance can be treated as a linguistic variable defined in the closed interval (Zadeh, 1965). For example, the expression "a service quality importance degree" represents a linguistic variable in the context of this study. It means the importance of a service quality that students experience during their studies at the university. The possible values for this variable could be: "very unimportant", "unimportant", "fair", "important", and "very important." For instance, in the value such as "fair", the membership functions of the expression values can be indicated by triangular fuzzy numbers $\mu_{\mathrm{A}}(\mathrm{X})=$ (lower value; medium value; upper value) within the scale range of [0100], the evaluators can subjectively assume their personal range of the linguistic variable $\mu_{\mathrm{A}}($ fair $)=(20 ; 50$; 80 ), which are shown in Figure 1. Compared with the traditional approach, the importance degree for the service attribute used n-points of the Likert scale and applied triangular fuzzy numbers to utilize linguistic variables (Benitez et al., 2007; Lin, 2010).

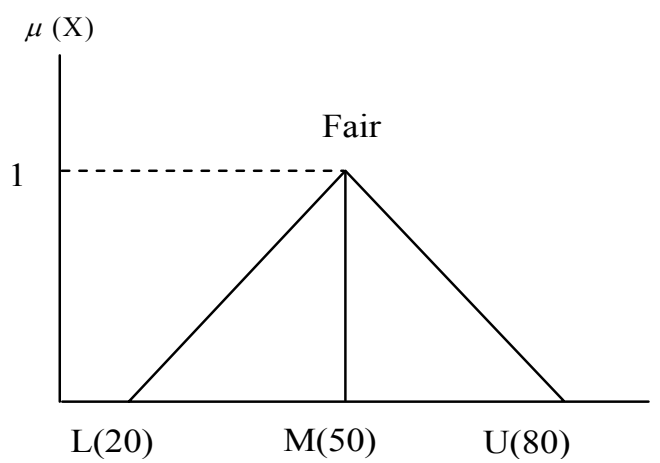

Figure 1. Triangular membership function of fuzzy number. L: lower value, M: medium value, U: upper value.

According to Zadeh (1965), there were some algebraic operations of the triangular fuzzy number.

Addition notation $(+)$

$\left(\mathrm{L}_{1}, \mathrm{M}_{1}, \mathrm{U}_{1}\right)+\left(\mathrm{L}_{2}, \mathrm{M}_{2}, \mathrm{U}_{2}\right)=\left(\mathrm{L}_{1}+\mathrm{L}_{2}, \mathrm{M}_{1}+\mathrm{M}_{2}, \mathrm{U}_{1}+\mathrm{U}_{2}\right)$

Subtraction (-)

$\left(\mathrm{L}_{1}, \mathrm{M}_{1}, \mathrm{U}_{1}\right)-\left(\mathrm{L}_{2}, \mathrm{M}_{2}, \mathrm{U}_{2}\right)=\left(\mathrm{L}_{1}-\mathrm{L}_{2}, \mathrm{M}_{1}-\mathrm{M}_{2}, \mathrm{U}_{1}-\mathrm{U}_{2}\right)$

Multiplication $(\cdot)$

$\left(\mathrm{L}_{1}, \mathrm{M}_{1}, \mathrm{U}_{1}\right) \cdot\left(\mathrm{L}_{2}, \mathrm{M}_{2}, \mathrm{U}_{2}\right)=\left(\mathrm{L}_{1} / \mathrm{L}_{2}, \mathrm{M}_{1} \mathrm{M}_{2}, \mathrm{U}_{1} \mathrm{U}_{2}\right)$

$\mathrm{L}_{1} \geq 0, \mathrm{~L}_{2} \geq 0$ 
For any real number $\mathrm{K}$,

$\mathrm{K} \cdot \mu_{\mathrm{A}}(\mathrm{X})=(\mathrm{K}, \mathrm{K}, \mathrm{K}) \cdot(\mathrm{L}, \mathrm{M}, \mathrm{U})=(\mathrm{KL}, \mathrm{KM}, \mathrm{KU})$

\subsection{Kano and Refined Kano Model}

In the quality management area, many methods are available for investigating and assessing the service quality performance of the service providers. The Kano model has been mostly applied within the quality management area. Kano et al. (1984) proposed a model that was inspired from Herzberg's motivator-hygiene model. These two aspects were used by the authors to construct a twodimensional (or 'two-way') model. This model identified the quality attributes into five categories: they are attractive, must-be, one dimensional, indifferent, and reverse quality attributes.

1. Attractive: attributes that give satisfaction if present, but that result in no dissatisfaction if absent;

2. One-dimensional: attributes characterized by a linear relationship between the customers' perception of satisfaction and the degree of fulfillment of the attributes;

3. Must-be: attributes whose absence will result in customer dissatisfaction, but whose presence does not significantly contribute to the customer satisfaction;

4. Indifferent: attributes that result in neither satisfaction nor dissatisfaction, regardless of being fulfilled or not;

5. Reverse: attributes that result in dissatisfaction when fulfilled and in satisfaction when not fulfilled.

The Kano model has many applications. It has the advantages in classifying customer needs (Yang, 1993, 2005). However, trade-offs are sometimes necessary. If some service attributes cannot be met simultaneously for technical or financial reasons, the service providers should consider other criteria that have the greatest influence on customer satisfaction. To solve this problem, Yang (2005) proposed a refined Kano model by considering the degree of importance of the attributes as a perceived quality by customers. The degrees of importance were classified into two categories. If the degree of importance of an attribute was greater than the mean of the importance degree for all service quality attributes, that attribute has 'high' importance degree. It has 'low' importance degree if below the mean.

By adding the degree of importance, this refined model can help service providers in precisely evaluating the influences of various service quality attributes. The model effectively subdivided each of Kano's first four main categories-thus making a total of eight categories from the original four. In addition, the existence of a ninth category, Kano's category of 'reverse' attributes should also be noted. The redefinition of the categories of quality attributes according to the refined model allows service providers to make quality decisions with more precision (Yang, 2005). Table 1 lists the redefined categories of quality attributes obtained by refining the Kano model. Yang (2005) represented these quality attributes as illustrated in Figure 2.

Table 1. Categories of quality attributes in refined Kano model

\begin{tabular}{|lcc|}
\hline \multicolumn{1}{|c}{$\begin{array}{c}\text { Categories of } \\
\text { Kano model }\end{array}$} & High importance & Low importance \\
\hline \hline Attractive & Highly attractive & Less attractive \\
One-dimensional & High value-added & Low value-added \\
Must-be & Critical & Necessary \\
Indifferent & Potential & Care-free \\
\hline
\end{tabular}

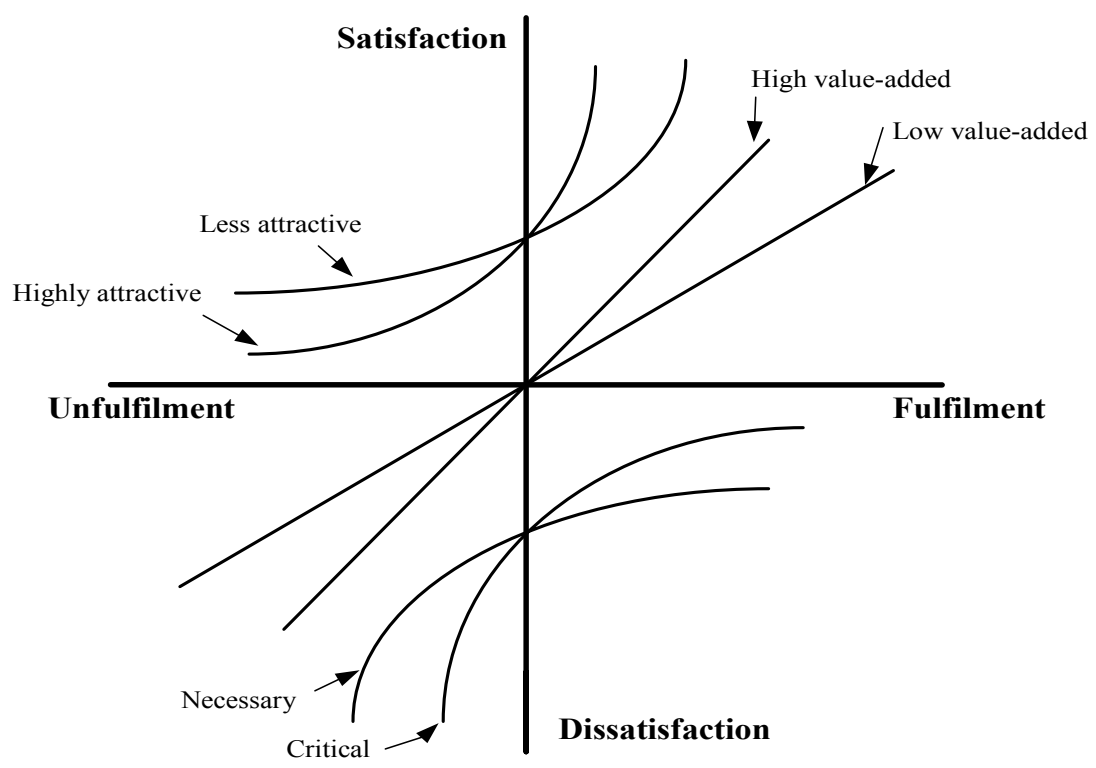

Figure 2. Refined Kano model of quality attributes. 


\subsection{Blue Ocean Strategy}

Kim and Mauborgne (2005) have proposed the "blue ocean" approach, which emphasizes avoiding competition while creating value innovation that drives down costs and simultaneously driving up value for buyers. What BOS seeks to do is to make the creation and capturing of blue oceans as systematic and actionable as competing in the red waters of known market space. Kim and Mauborgne (2005) believed that customers make purchase decisions based on the offering's attributes, such as quality, availability, and price. They advise that managers discover blue oceans by experimenting with and developing innovative bundles of attributes which break the accepted cost-differentiation trade-off (Sheehan and Vaidyanathan, 2009). Kim and Mauborgne (2005) put forward "the eliminate-reduce-raise-create (ERRC) grid" to help managers conceive and design new bundles of attributes. The ERRC practical actions reconstruct customer value perceptions by answering four aspects of the grid (Table 2).

The four aspects of the grid can be briefly summarized as follows (Yang and Yang, 2011):

1. Eliminate: to reduce costs, any factors or elements that no longer have value for customers (or might even detract from value for customers) can be eliminated;

2. Reduce: any attributes of products or services that have been over-designed in an attempt to match and beat the competition, or attributes that have little attraction to customers, and which are therefore increasing their cost structure for no gain, should be reduced;
3. Raise: attributes that can result in significant value for customers, or those that have high attraction to customers, should be assessed with a view to raising their fulfillment;

4. Create: factors that can produce entirely new sources of value for customers, or factors that can create new demand and attract non-customers, should be created.

Table 2. The ERRC grid

\begin{tabular}{|ll|}
\hline \multicolumn{1}{|c|}{ Eliminate } & \multicolumn{1}{c|}{ Reduce } \\
\hline \hline $\begin{array}{l}\text { Those factors or elements } \\
\text { that no longer have value or } \\
\text { may even detract from value } \\
\text { for customers }\end{array}$ & $\begin{array}{l}\text { Those attributes that have } \\
\text { been over-designed in the } \\
\text { race of competition or those } \\
\text { have little attraction of cus- } \\
\text { tomers }\end{array}$ \\
\hline \multicolumn{1}{|c|}{ Raise } & \multicolumn{1}{c|}{ Create } \\
\hline $\begin{array}{l}\text { Those attributes that can re- } \\
\text { sult in significant value for } \\
\text { customers or those that have } \\
\text { high attraction to customers }\end{array}$ & $\begin{array}{l}\text { Those factors that can dis- } \\
\text { cover new sources of value } \\
\text { for customers or those that } \\
\text { can create new demand and } \\
\text { attract non customers }\end{array}$ \\
\hline
\end{tabular}

\section{THE DEVELOPMENT OF AN INTEGRATED MODEL}

In this part, we will propose an integrated model of determining the critical attributes and their appropriate actions. To address these challenges, an integrated model framework is created to provide a traceable flow-down from the identification of service attributes to the appro-

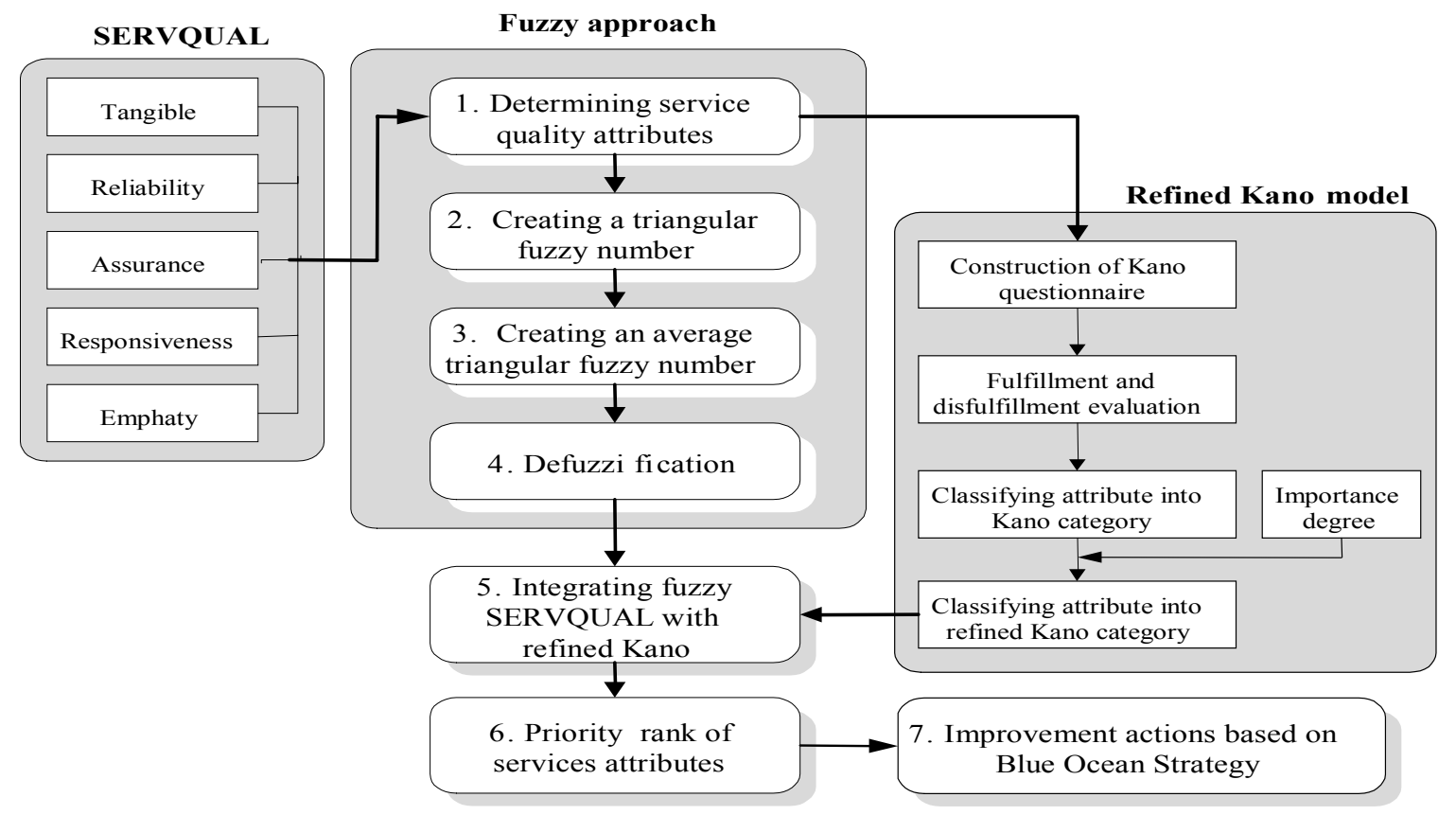

Figure 3. An integrated model of determining the critical attributes and their appropriate actions. 
priate practical actions. A basic taxonomy of this methodology is created based on the fuzzy approach steps. Subsequently, the SERVQUAL, refined Kano and blue ocean model are integrated into a hierarchical model to allow the validity of the result. A structure with seven basic steps will be proposed for determining the priority of the critical service attributes and their appropriate actions. Figure 3 provides the integrated model in conducting this study.

\section{AN EMPIRICAL CASE STUDY}

\subsection{Sampling and Data Collection}

The survey for the higher education area covered the quality of various services offered for students as the primary customers. In this research, one of Indonesia's wellestablished private universities in Jakarta will be used for further discussion in order to illustrate the implementation of the integrated model. This empirical study analyzed the critical students' expectations of service quality at a higher education institution. Questionnaires were designed according to the SERVQUAL model of measuring service expectation (Parasuraman et al., 1988). The survey instrument (questionnaires) consisted of three sections: 1) statements focused on student expectations of service quality at a private university, 2) demographic data about respondents (faculty, year of study and gender), and 3) functional-dysfunctional statements for the refined Kano model.

Table 3. Student respondent profile $(n=384)$

\begin{tabular}{|lcc|}
\hline \multirow{2}{*}{ Description } & \multicolumn{2}{c|}{ No. of respondents } \\
\cline { 2 - 3 } & Frequencies & $\%$ \\
\hline \hline Faculty & 171 & 44.53 \\
Economics & 24 & 6.25 \\
Business Administration & 31 & 8.07 \\
Education & 47 & 12.24 \\
Engineering & 45 & 11.72 \\
Law & 25 & 6.51 \\
Medical & 31 & 8.07 \\
Psychology & 10 & 2.60 \\
Biotechnology & & \\
Year of study & 98 & 25.52 \\
1st & 123 & 32.03 \\
2nd & 88 & 22.92 \\
3rd & 75 & 19.53 \\
4th & & \\
Gender & 185 & 48.17 \\
Male & 199 & 51.83 \\
Female &
\end{tabular}

A pilot study of a sample size of 50 was conducted at a university environment to ensure the user-friendliness of the designed questionnaires. All the students responding to the questionnaires commented on its readability and ease of understanding. As a result, no amendment in terms of rewording of items was made. Service quality surveys were conducted in the academic year 2008/2009 with all-year undergraduate students. Students were given verbal and written instructions, and completed the questionnaires. Of the 400 students surveyed for this study, 384 returned usable questionnaires giving a response rate of $96 \%$. This was considered an adequate sample size, since other scale developers in the marketing area had used a sample size of 200 to analyze group data (Parasuraman et al., 1985). All data were collected over a period of 3 months.

There was a sample of 384 undergraduate students of a private university, comprised of $48.17 \%$ male and $51.83 \%$ female respondents (Table 3 ). Within the sample, $25.52 \%$ of the students were in their first year, $32.03 \%$ in their second year, $22.92 \%$ in their third year, and $19.53 \%$ in their final year. Most of the students (44.53\%) were undergraduate students of the Economics Faculty.

\subsection{Data Analysis}

To deeply understand the integrated model, this research provides some systematic steps of the integration model of fuzzy SERVQUAL and the refined Kano model. This section will illustrate and analyze each individual step in what follows:

\subsubsection{Determining service quality attributes}

First, a total of 30 students were randomly interviewed. The students were asked to think of learning experiences in the university (positive and negative critical incidents) and to indicate the relevant attributes of the higher education institution to increase the student satisfaction owing to the service expected and received. At the same time, the nominal group technique was used to conduct a panel discussion. The participants of the discussion included university stakeholders such as students, lecturers, administration staffs, parents, and university's leader representatives. The interview and discussion material were derived from five SERVQUAL dimensions of the Parasuraman et al. (1988)'s service quality, to measure service contact. The wording of some of the original attributes has been modified in an attempt to avoid confusing sentences which did not form part of the vocabulary used in the sector of higher education which was analyzed. The purpose of students' interviews and a panel discussion was to determine the service attributes to be listed in the final questionnaire. As a result, five SERVQUAL dimensions (consisting of 29 service attributes) developed for this study are set out in Table 4. Rearranging the service attributes (based on SERVQUAL dimensions) obtained from the interviews, a panel discussion, and the experiential knowledge of the authors in this sector, five basic dimensions are proposed for higher education service quality (Table 5). 
Table 4. Five SERVQUAL dimensions and 29 service attributes

\begin{tabular}{|c|c|}
\hline $\begin{array}{l}\text { SERVQUAL } \\
\text { dimensions }\end{array}$ & Service attributes \\
\hline Realibility & $\begin{array}{l}\text { The university makes a commitment to provide a service at the scheduled time } \\
\text { The university keeps students' records accurately (e.g., test scores, student names) } \\
\text { Relevant and up to date literature and lecture material } \\
\text { Literatures and lecture materials can be easily understood } \\
\text { Good and understandable teaching performance }\end{array}$ \\
\hline Responsiveness & $\begin{array}{l}\text { Important announcement is quickly informed to students (e.g., lectures schedule, exam schedule) } \\
\text { The university is always ready to help students } \\
\text { Clear notice about assignments and exams } \\
\text { Lecturers recommend appropriate text book } \\
\text { The university provides consultation time for students }\end{array}$ \\
\hline Assurance & $\begin{array}{l}\text { Lecturers have the required knowledge and education } \\
\text { Students are equipped with good quality to work } \\
\text { Availability of career service for graduates } \\
\text { Safe environment } \\
\text { Lecturers have the ability to answer questions from students } \\
\text { Friendly environment and respect each other }\end{array}$ \\
\hline Emphaty & $\begin{array}{l}\text { Lecturers give relevant and appropriate tasks } \\
\text { The availability of scholarship for students with good achievement } \\
\text { Ease of obtaining lecture material } \\
\text { Ease of administration related with the curriculum (e.g., payments procedure, courses selection) } \\
\text { The university gives individual attention to each student } \\
\text { Effective communication between university and students }\end{array}$ \\
\hline Tangibles & $\begin{array}{l}\text { The university provides the facilities that can be used to develop students' interest and talent (e.g., sport } \\
\text { facilities, student activities club, etc.) } \\
\text { Employees should be well dressed, appear neat, and professional } \\
\text { The university provides the up to date equipments to support learning process (e.g., lab equipment, } \\
\text { learning equipment in class, etc.) } \\
\text { Clean environment (classroom, toilet, canteen, etc.) } \\
\text { Library provides up to date learning source (e.g., books, journal, etc.) } \\
\text { Campus cafeteria sells clean food with affordable price } \\
\text { The availability of computer and internet access }\end{array}$ \\
\hline
\end{tabular}

\subsubsection{Creating a triangular fuzzy number for student's} importance, perception, and expectation term

The questionnaire of service quality evaluation is mainly composed of 29 questions for evaluating the HEI's performance corresponding to each attribute. Generally, surveys examining importance degree, student perceptions and expectation of service quality have used questionnaires in which respondents indicate their feelings with reference to selected linguistic terms. But human judgments of events may vary significantly according to the subjective perceptions or personality of individuals. This study used a triangular fuzzy number to represent the linguistic term of importance degree, student's perception and expectation or service quality.

Moreover, we used the membership function associated with each linguistic expression term, according to the representative triangular fuzzy numbers. We asked students to specify the experimented quality of the service of each service attribute with linguistic expression. The linguistic terms from which students chose to indicate their perception and expectation towards service are: poor, fair, good, very good, excellent and very unimportant, unimportant, fair, important, very important for indicating im- portance degree. In the survey questionnaire of this study, students were asked to complete the question about the range of each linguistic term based on their own subjective decision. For example, one respondent gave triplets $(0,0,2),(0,2,4),(2,4,6),(4,6,8)$, and $(6,8,8)$ meaning very unimportant/poor, unimportant/fair, fair/good, important/very good, and very important/excellent, respectively (Figures 4 and 5). These scores are later aggregated to calculate the average importance, perception, and expectation as a new triangular fuzzy number for each attribute.

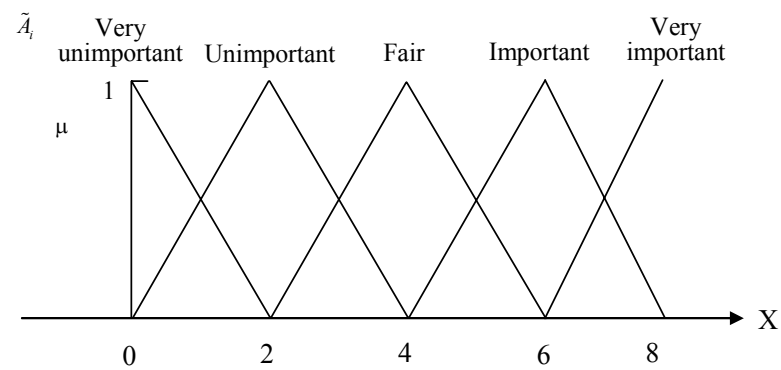

Figure 4. The student's linguistic importance term. 
Tabel 5. Service attributes of higher education institution

\begin{tabular}{|c|c|}
\hline \multirow[t]{5}{*}{ A } & Academic Atmosphere \\
\hline & Safe environment \\
\hline & Clean environment (classroom, toilet, canteen, etc) \\
\hline & Friendly environment and respect each other \\
\hline & Effective communication between university and students \\
\hline \multirow[t]{8}{*}{ B } & Human Resources \\
\hline & Employees should be well dressed, appear neat, and professional \\
\hline & The university gives individual attention to each student (e.g. academic supervisors) \\
\hline & Lecturers have the required knowledge and education \\
\hline & The university is always ready to help students \\
\hline & The university provides consultation time for students \\
\hline & The university keeps their records accurately (e.g. test scores, student names, etc.) \\
\hline & The university makes a commitment to provide a service at the scheduled time \\
\hline \multirow[t]{8}{*}{$\mathbf{C}$} & Learning System \\
\hline & Good and understandable teaching performance \\
\hline & Lecturers recommend appropriate text book \\
\hline & Lecturers have the ability to answer questions from students \\
\hline & Lecturers give relevant and appropriate tasks \\
\hline & Important announcement is quickly informed to students (e.g., lectures schedule, exam schedule, etc.) \\
\hline & Students are equipped with good quality to work \\
\hline & The availability of scholarship for students with good achievement \\
\hline \multirow[t]{5}{*}{ D } & Academic Information Systems \\
\hline & Ease of administration related with the curriculum (e.g., payments procedure, courses selection, etc.) \\
\hline & Clear notice about assignments and exams \\
\hline & Ease of obtaining lecture material \\
\hline & Relevant and up to date literature and lecture material \\
\hline \multirow[t]{8}{*}{$\mathbf{E}$} & Facilities \\
\hline & Literatures and lecture materials can be easily understood \\
\hline & $\begin{array}{l}\text { The university provides the facilities that can be used to develop students' interest and talent (e.g., sport fa- } \\
\text { cilities, student activities club, etc.) }\end{array}$ \\
\hline & $\begin{array}{l}\text { The university provides the up to date equipments to support learning process (e.g., lab equipment, learning } \\
\text { equipment in class, etc.) }\end{array}$ \\
\hline & Library provides up to date learning source (e.g., books, journal, etc.) \\
\hline & Availability of career service for graduates \\
\hline & Campus cafeteria sells clean food with affordable price \\
\hline & The availability of computer and internet access \\
\hline
\end{tabular}

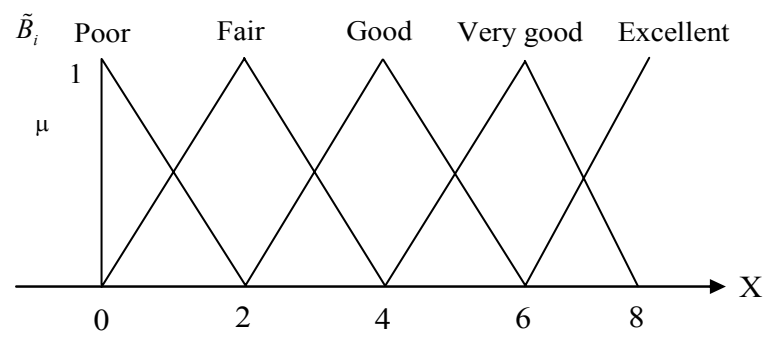

Figure 5. The student's linguistic perception and expectation terms.
4.2.3 Creating an average triangular fuzzy number from $\mathrm{n}$ triangular fuzzy numbers

Linguistic terms, importance degree and satisfaction degree (perception and expectation) are often vague. To provide more objective student assessment for a higher education institution, after we created a triangular fuzzy number for the importance degree, perception, and expectation as triangular fuzzy numbers individually, we apply Eq. (6) for importance term and Eq. (7) for perception and expectation terms in order to aggregate student opinions. 


$$
\begin{aligned}
\tilde{A} & =A_{\text {ave }}=\frac{\tilde{A}_{1}+\tilde{A}_{2}+\cdots+\tilde{A}_{n}}{n} \\
& =\frac{\left(\sum_{i=1}^{n} a_{1}^{(i)}, \sum_{i=1}^{n} a_{2}^{(i)}, \sum_{i=1}^{(i)} a_{3}^{(i)}\right)}{n}=\left(a_{1}, a_{2}, a_{3}\right) \\
\tilde{B} & =B_{\text {ave }}=\frac{\tilde{B}_{1}+\tilde{B}_{2}+\cdots+\tilde{B}_{n}}{n} \\
& =\frac{\left(\sum_{i=1}^{n} b_{1}^{(i)}, \sum_{i=1}^{n} b_{2}^{(i)}, \sum_{i=1}^{(i)} b_{3}^{(i)}\right)}{n}=\left(b_{1}, b_{2}, b_{3}\right)
\end{aligned}
$$

$A_{\text {ave }}$ in Eq. (6) and $B_{\text {ave }}$ in Eq. (7) denote the average fuzzy number of $\mathrm{n}$ triangular numbers.

Table 6 lists the average fuzzy numbers of importance, perception, expectation measure for a survey done in a private university in Jakarta, Indonesia.

\subsubsection{Defuzzification}

After obtaining the importance, perception, and expectation measure in terms of fuzzy numbers, we need to defuzzify the fuzzy numbers into crisp numbers. We used a common method to defuzzify the fuzzy numbers. Table 7 shows the defuzzied importance, perception, and expectation values of each service attribute for the surveys.

\subsubsection{Integrating fuzzy SERVQUAL result with refined}

Kano model

The attributes are evaluated using the three steps of evaluation from the Kano model. After having combined the answers to fulfillment-disfulfillment questions and importance degree, the results of the service attributes are listed in the table of results which shows the overall distribution of the Kano categories and the refined Kano categories (Table 8).

\subsubsection{Determining the rank order of critical services at- tributes}

\begin{tabular}{|c|c|c|c|}
\hline No. & Importance & Perception & Expectation \\
\hline A1 & $(5.234,7.398,7.887)$ & $(4.321,5.459,6.943)$ & $(4.567,6.537,7.898)$ \\
\hline A2 & $(4.456,7.458,7.789)$ & $(3.565,5.425,6.789)$ & $(3.456,6.244,7.897)$ \\
\hline A3 & $(5.456,7.509,7.790)$ & $(3.456,5.636,7.231)$ & $(4.678,6.373,7.567)$ \\
\hline A4 & $(6.451,7.256,7.898)$ & $(3.897,5.939,7,345)$ & $(4.567,6.555,7.543)$ \\
\hline $\mathrm{B} 1$ & $(4.678,6.890,7.765)$ & $(4.521,5.763,7.567)$ & $(4.847,6.888,7.653)$ \\
\hline B2 & $(5.234,7.119,7.656)$ & $(3.787,5.881,6.789)$ & $(4.347,6.555,7.543)$ \\
\hline B3 & $(6.321,7.687,7.890)$ & $(4.787,5.561,7.789)$ & $(4.567,6.565,6.998)$ \\
\hline B4 & $(6.212,7.578,7.890)$ & $(3.981,5.761,6.749)$ & $(4.567,6.575,7.555)$ \\
\hline B5 & $(5.673,7.413,7.678)$ & $(3.562,5.497,7.432)$ & $(3.456,6.244,7.897)$ \\
\hline B6 & $(5.698,7.218,7.893)$ & $(4.329,5.615,7.234)$ & $(4.446,6.254,7.847)$ \\
\hline B7 & $(5.567,7.226,7.987)$ & $(4.521,5.715,7.837)$ & $(4.561,6.275,7.666)$ \\
\hline $\mathrm{C} 1$ & $(5.456,7.509,7.790)$ & $(3.565,5.425,6.789)$ & $(3.456,6.244,7.797)$ \\
\hline $\mathrm{C} 2$ & $(5.556,7.609,7.890)$ & $(4.465,5.785,7.789)$ & $(4.557,6.674,7.444)$ \\
\hline $\mathrm{C} 3$ & $(5.456,7.509,7.790)$ & $(3.256,5.736,6.831)$ & $(3.456,6.247,7.897)$ \\
\hline $\mathrm{C} 4$ & $(5.234,7.119,7.656)$ & $(3.897,5.929,7,315)$ & $(3.656,6.644,7.798)$ \\
\hline $\mathrm{C} 5$ & $(6.212,7.578,7.890)$ & $(4.676,5.278,6.893)$ & $(3.456,6.242,7.897)$ \\
\hline C6 & $(5.356,7.609,7.890)$ & $(3.562,5.497,7.432)$ & $(4.596,6.371,7.891)$ \\
\hline $\mathrm{C} 7$ & $(5.456,7.509,7.790)$ & $(3.862,5.897,7.332)$ & $(4.556,6.278,7.597)$ \\
\hline D1 & $(4.456,7.458,7.789)$ & $(4.565,5.425,6.789)$ & $(3.456,6.244,7.897)$ \\
\hline D2 & $(5.436,7.609,7.790)$ & $(4.975,5.725,6.989)$ & $(4.516,6.564,7.391)$ \\
\hline D3 & $(5.673,7.413,7.678)$ & $(3.787,5.881,6.789)$ & $(3.456,6.244,7.897)$ \\
\hline D4 & $(5.456,7.509,7.690)$ & $(4.787,5.983,6.889)$ & $(3.345,6.504,7.525)$ \\
\hline E1 & $(6.456,7.529,7.890)$ & $(3.562,5.497,7.432)$ & $(4.567,6.555,7.529)$ \\
\hline E2 & $(5.234,7.119,7.656)$ & $(3.862,5.594,7.531)$ & $(3.537,6.543,7.890)$ \\
\hline E3 & $(6.212,7.578,7.890)$ & $(3.565,5.425,6.789)$ & $(3.483,6.341,7.541)$ \\
\hline E4 & $(6.212,7.678,7.990)$ & $(4.565,5.825,6.749)$ & $(4.567,6.525,7.743)$ \\
\hline E5 & $(4.456,7.458,7.789)$ & $(4.475,5.456,6.789)$ & $(5.565,6.765,7.556)$ \\
\hline E6 & $(5.673,7.413,7.678)$ & $(3.787,5.881,6.789)$ & $(4.567,6.505,7.543)$ \\
\hline E7 & $(6.321,7.555,7.887)$ & $(3.215,5.652,6.789)$ & $(4.557,6.789,7.893)$ \\
\hline
\end{tabular}

The next step is to determine the rank order of the critical attributes and interpret the result. By combining the

Table 6. Average triangular fuzzy numbers of importance, perception, and expectation measure 
Table 7. Overall importance, perception, and expectation measures

\begin{tabular}{|c|c|c|c|c|}
\hline No. & Service quality attributes & $\begin{array}{l}\text { Importance } \\
\text { value }\end{array}$ & $\begin{array}{l}\text { Perception } \\
\text { value }\end{array}$ & $\begin{array}{l}\text { Expectation } \\
\text { value }\end{array}$ \\
\hline A1 & Safe environment & 7.3984 & 5.285 & 6.137 \\
\hline $\mathrm{A} 2$ & Clean environment (classroom, toilet, canteen, etc.) & 7.4583 & 5.225 & 6.134 \\
\hline A3 & Friendly environment and respect each other & 7.3099 & 5.436 & 6.073 \\
\hline A4 & Effective communication between university and students & 7.2005 & 5.539 & 6.055 \\
\hline B1 & Employees should be well dressed, appear neat, and professional & 6.8307 & 5.663 & 5.993 \\
\hline B2 & The university gives individual attention to each student & 6.9193 & 5.181 & 6.061 \\
\hline B3 & Lecturers have the required knowledge and education & 7.6771 & 5.402 & 6.131 \\
\hline B4 & The university is always ready to help students & 7.2786 & 5.121 & 6.051 \\
\hline B5 & The university provides consultation time for students & 7.2135 & 5.097 & 5.944 \\
\hline B6 & The university keeps their records accurately & 7.2188 & 5.115 & 6.087 \\
\hline B7 & $\begin{array}{l}\text { The university makes a commitment to provide a service at the } \\
\text { scheduled time }\end{array}$ & 7.2266 & 5.118 & 6.125 \\
\hline $\mathrm{C} 1$ & Good and understandable teaching performance & 7.513 & 5.266 & 6.043 \\
\hline $\mathrm{C} 2$ & Lecturers recommend appropriate text book & 7.1901 & 5.255 & 5.985 \\
\hline $\mathrm{C} 3$ & Lecturers have the ability to answer questions from students & 7.3776 & 5.124 & 6.077 \\
\hline $\mathrm{C} 4$ & Lecturers give relevant and appropriate tasks & 7.0833 & 5.292 & 5.951 \\
\hline $\mathrm{C} 5$ & Important announcement is quickly informed to students & 7.3932 & 4.978 & 6.032 \\
\hline C6 & Students are equipped with good quality to work & 7.4505 & 5.267 & 6.066 \\
\hline $\mathrm{C} 7$ & $\begin{array}{l}\text { The availability of scholarship for students with good achieve- } \\
\text { ment }\end{array}$ & 7.3255 & 5.358 & 6.124 \\
\hline D1 & Ease of administration related with the curriculum & 7.3021 & 5.082 & 6.039 \\
\hline D2 & Clear notice about assignments and exams & 7.2708 & 5.193 & 6.06 \\
\hline D3 & Ease of obtaining lecture material & 7.1719 & 5.137 & 6.067 \\
\hline D4 & Relevant and up to date literature and lecture material & 7.3516 & 5.243 & 6.059 \\
\hline E1 & Literatures and lecture materials can be easily understood & 7.2891 & 5.269 & 6.119 \\
\hline E2 & $\begin{array}{l}\text { The university provides the facilities that can be used to develop } \\
\text { students' interest and talent }\end{array}$ & 7.0625 & 5.117 & 6.043 \\
\hline E3 & $\begin{array}{l}\text { The university provides the up to date equipments to support } \\
\text { learning process }\end{array}$ & 7.3047 & 5.082 & 6.025 \\
\hline E4 & Library provides up to date learning & 7.4323 & 5.151 & 6.041 \\
\hline E5 & Availability of career service for graduates & 7.0833 & 4.966 & 6.065 \\
\hline E6 & Campus cafeteria sells clean food with affordable price & 7.2552 & 5.011 & 6.023 \\
\hline E7 & The availability of computer and internet access & 7.4557 & 5.152 & 6.134 \\
\hline
\end{tabular}

category from Table 8 and gap score from perception and expectation value, the rank order of the critical level of service attributes can be determined as shown in Table 9.

\subsubsection{Determining appropriate improvement actions based on blue ocean strategy \\ The last step is to choose the 10 most critical service} attributes based on the priority rank and to determine their appropriate practical actions using the four-action framework of BOS (Table 10).

\section{FINDINGS AND DISCUSSION}

Service quality in education has evolved and taken varying forms all over the world in terms of customer satisfaction and issues of assessment. The focus of this study is essentially on understanding the students' requirements with the ultimate objective of delighting the students as primary customers. A study was conducted on student's perspectives as primary customers of the educational system. The satisfaction of students would always be a precondition to customer orientation and satisfaction of the primary customer. Thus, this paper restricts itself to the findings obtained from the students as primary customer of the educational system. The ultimate objective was to identify such design service characteristics that would meet their requirements as customers and lead to satisfaction. Through integration of the fuzzy SERVQUAL, refined Kano, and blue ocean strategy, the critical service 
Table 8. The overall distribution of the Kano and refined Kano categories

\begin{tabular}{|c|c|c|c|c|c|c|c|c|c|c|c|}
\hline No. & $\mathrm{A}$ & $\mathrm{M}$ & $\mathrm{O}$ & I & $\mathrm{R}$ & Q & Importance & $(\mathrm{A}+\mathrm{M}+\mathrm{O})$ & $(\mathrm{I}+\mathrm{R}+\mathrm{Q})$ & Kano & Refined Kano \\
\hline A1 & 7 & 73 & 274 & 30 & 0 & 0 & 7.398 & 354 & 30 & $\mathrm{O}$ & High value-added \\
\hline A2 & 26 & 76 & 222 & 60 & 0 & 0 & 7.458 & 324 & 60 & $\mathrm{O}$ & High value-added \\
\hline $\mathrm{A} 3$ & 49 & 68 & 57 & 210 & 0 & 0 & 7.309 & 174 & 210 & I & Potential \\
\hline A4 & 41 & 188 & 76 & 79 & 0 & 0 & 7.2 & 305 & 79 & $\mathrm{M}$ & Necessary \\
\hline B1 & 60 & 80 & 44 & 200 & 0 & 0 & 6.83 & 184 & 200 & I & Care-free \\
\hline B2 & 34 & 50 & 223 & 77 & 0 & 0 & 6.919 & 307 & 77 & $\mathrm{O}$ & Low value-added \\
\hline B3 & 12 & 46 & 273 & 53 & 0 & 0 & 7.677 & 331 & 53 & $\mathrm{O}$ & High value-added \\
\hline B4 & 32 & 55 & 232 & 65 & 0 & 0 & 7.278 & 319 & 65 & $\mathrm{O}$ & High value-added \\
\hline B5 & 43 & 68 & 194 & 79 & 0 & 0 & 7.213 & 305 & 79 & $\mathrm{O}$ & Low value-added \\
\hline B6 & 40 & 64 & 80 & 200 & 0 & 0 & 7.218 & 184 & 200 & I & Care-free \\
\hline B7 & 48 & 57 & 171 & 108 & 0 & 0 & 7.226 & 276 & 108 & $\mathrm{O}$ & Low value-added \\
\hline $\mathrm{C} 1$ & 36 & 195 & 47 & 106 & 0 & 0 & 7.513 & 278 & 106 & M & Critical \\
\hline $\mathrm{C} 2$ & 65 & 55 & 152 & 112 & 0 & 0 & 7.19 & 372 & 112 & $\mathrm{O}$ & Low value-added \\
\hline $\mathrm{C} 3$ & 28 & 120 & 36 & 200 & 0 & 0 & 7.377 & 184 & 200 & I & Potential \\
\hline $\mathrm{C} 4$ & 23 & 41 & 94 & 226 & 0 & 0 & 7.083 & 158 & 226 & I & Care-free \\
\hline $\mathrm{C} 5$ & 39 & 62 & 202 & 81 & 0 & 0 & 7.393 & 303 & 81 & $\mathrm{O}$ & High value-added \\
\hline $\mathrm{C} 6$ & 19 & 64 & 254 & 47 & 0 & 0 & 7.45 & 337 & 47 & $\mathrm{O}$ & High value-added \\
\hline $\mathrm{C} 7$ & 183 & 47 & 62 & 92 & 0 & 0 & 7.325 & 292 & 92 & A & Highly attractive \\
\hline D1 & 41 & 50 & 220 & 73 & 0 & 0 & 7.302 & 311 & 73 & $\mathrm{O}$ & High value-added \\
\hline D2 & 38 & 77 & 52 & 217 & 0 & 0 & 7.27 & 167 & 217 & I & Care-free \\
\hline D3 & 229 & 23 & 39 & 93 & 0 & 0 & 7.171 & 291 & 93 & A & Less attractive \\
\hline D4 & 32 & 199 & 86 & 67 & 0 & 0 & 7.351 & 317 & 67 & M & Critical \\
\hline E1 & 48 & 169 & 78 & 89 & 0 & 0 & 7.289 & 295 & 89 & M & Critical \\
\hline E2 & 86 & 115 & 67 & 116 & 0 & 0 & 7.062 & 268 & 116 & M & Necessary \\
\hline E3 & 166 & 71 & 53 & 94 & 0 & 0 & 7.304 & 290 & 94 & A & Highly attractive \\
\hline E4 & 43 & 180 & 67 & 94 & 0 & 0 & 7.432 & 290 & 94 & M & Critical \\
\hline E5 & 73 & 45 & 111 & 155 & 0 & 0 & 7.038 & 229 & 155 & $\mathrm{O}$ & Low value-added \\
\hline E6 & 178 & 47 & 39 & 120 & 0 & 0 & 7.255 & 264 & 120 & A & Less attractive \\
\hline E7 & 136 & 61 & 58 & 129 & 0 & 0 & 7.455 & 255 & 129 & A & Highly attractive \\
\hline \multicolumn{7}{|c|}{ Average } & 7.2774 & & & & \\
\hline
\end{tabular}

A: attractive, M: must-be, O: one-dimensional, I: indifferent, R: reverse, Q: questionnaire.

attributes and the improvement actions that would meet the requirements of the students were affirmed qualitatively and quantitatively. Against this backdrop, it becomes imperative that a theoretical and conceptual framework is laid out and an integrated model proposed.

For the purpose of this study, 5 higher education aspects and 29 attributes are developed by reviewing previous studies as well as collecting expert opinions. These service quality criteria could lead to satisfaction and dissatisfaction. Through questionnaires, each student can be asked to give the following data: 1) a triangular fuzzy number corresponding to each of the linguistic values (e.g., poor, fair, good, very good, and excellent), 2) a category of each quality attribute as improvement priority. The category classification for each attribute is represented by the refined Kano model.

This study suggests that the strategies to satisfying the students' needs of a private university in Jakarta, Indonesia can be determined. The strategies can be made based on the students' preferences. One of the important strategies in the university's success is how to prioritize the appropriate actions. From the perspective of students, the service quality improvement priority is determined based on the SERVQUAL gap score and the refined Kano model result. The appropriate action for each attribute is determined based on the blue ocean strategy.

In accordance with the result, the university has to develop the core competence required to raise the fulfillment level of the 'critical' attributes-for example, up-todate learning of the library (E4), literatures and lecture materials that can be easily understood (E1), relevant and up to date literature and lecture material (D4), and good and understandable teaching performance (C1). Moreover, to delight the students' needs, the university also should create 'high attractive' attributes in the availability of the computer and internet access (E7), the up-to-date equipments to the support learning processes (E3), and the availability of scholarship for students with good achievement (C7). In addition, the following attributes should be noted: 
Table 9. The rank order of critical level of service attributes

\begin{tabular}{|ccccccc|}
\hline No. & Perception & Expectation & Gap score & Category in Kano model & Category in refined Kano model & Priority rank \\
\hline \hline A1 & 5.285 & 6.137 & -0.852 & O & High value-added & 16 \\
A2 & 5.228 & 6.134 & -0.909 & O & High value-added & 15 \\
A3 & 5.436 & 6.073 & -0.637 & I & Potential & 25 \\
A4 & 5.539 & 6.055 & -0.516 & M & Necessary & 6 \\
B1 & 5.663 & 5.993 & -0.33 & I & Care-free & 29 \\
B2 & 5.181 & 6.061 & -0.88 & O & Low value-added & 21 \\
B3 & 5.402 & 6.131 & -0.729 & O & High value-added & 18 \\
B4 & 5.121 & 6.051 & -0.93 & O & High value-added & 14 \\
B5 & 5.097 & 5.944 & -0.846 & O & Low value-added & 22 \\
B6 & 5.115 & 6.087 & -0.972 & I & Care-free & 26 \\
B7 & 5.118 & 6.125 & -1.008 & O & Low value-added & 20 \\
C1 & 5.266 & 6.043 & -0.777 & M & Critical & 4 \\
C2 & 5.255 & 5.985 & -0.731 & O & Low value-added & 23 \\
C3 & 5.124 & 6.077 & -0.954 & I & Potential & 24 \\
C4 & 5.292 & 5.951 & -0.659 & I & Care-free & 28 \\
C5 & 4.978 & 6.032 & -1.054 & O & High value-added & 12 \\
C6 & 5.267 & 6.066 & -0.799 & O & High value-added & 17 \\
C7 & 5.358 & 6.124 & -0.766 & A & Highly attractive & 9 \\
D1 & 5.082 & 6.039 & -0.957 & O & High value-added & 13 \\
D2 & 5.193 & 6.06 & -0.867 & I & Care-free & 27 \\
D3 & 5.137 & 6.067 & -0.93 & A & Less attractive & 11 \\
D4 & 5.243 & 6.059 & -0.816 & M & Critical & 3 \\
E1 & 5.269 & 6.119 & -0.851 & M & Critical & 2 \\
E2 & 5.117 & 6.043 & -0.926 & M & Necessary & 5 \\
E3 & 5.082 & 6.025 & -0.942 & A & Highly attractive & 8 \\
E4 & 5.151 & 6.041 & -0.89 & M & Critical & 1 \\
E5 & 4.966 & 6.065 & -1.098 & O & Low value-added & 19 \\
E6 & 5.011 & 6.023 & -1.012 & A & Less attractive & 10 \\
E7 & 5.152 & 6.134 & -0.982 & A & & 7 \\
\hline
\end{tabular}

A: attractive, M: must-be, O: one-dimensional, I: indifferent.

Table 10. The 10 most critical service attributes and their appropriate actions

\begin{tabular}{|ccccccc|}
\hline $\begin{array}{c}\text { Service } \\
\text { attribute }\end{array}$ & Perception & Expectation & $\begin{array}{c}\text { Category in } \\
\text { Kano model }\end{array}$ & $\begin{array}{c}\text { Category in refined } \\
\text { Kano model }\end{array}$ & Priority & $\begin{array}{c}\text { Suggested } \\
\text { action }\end{array}$ \\
\hline E4 & 5.151 & 6.041 & $\mathrm{M}$ & Critical & 1 & Raise \\
E1 & 5.269 & 6.119 & $\mathrm{M}$ & Critical & 2 & Raise \\
D4 & 5.243 & 6.059 & $\mathrm{M}$ & Critical & 3 & Raise \\
C1 & 5.266 & 6.043 & $\mathrm{M}$ & Critical & 4 & Raise \\
E2 & 5.117 & 6.043 & $\mathrm{M}$ & Necessary & 5 & Maintain \\
A4 & 5.539 & 6.055 & $\mathrm{M}$ & Necessary & 6 & Maintain \\
E7 & 5.152 & 6.134 & $\mathrm{~A}$ & Highly attractive & 7 & Create, Raise \\
E3 & 5.082 & 6.025 & $\mathrm{~A}$ & Highly attractive & 8 & Create, Raise \\
C7 & 5.358 & 6.124 & $\mathrm{~A}$ & Highly attractive & 9 & Create, Raise \\
E6 & 5.011 & 6.023 & $\mathrm{~A}$ & Less attractive & 10 & Maintain, Reduce \\
\hline
\end{tabular}

1. The university should maintain the facilities that can be used to develop students' interest and talent (E2) (as a 'necessary' attribute);

2. The university should maintain an effective communication between the university and the students
(A4) (as a 'necessary' attribute);

3. The campus cafeteria sells clean food with affordable price (E6) as a 'less attractive' attribute. The university should maintain or reduce the price to delight the students. 


\section{CONCLUSION}

Service quality is vital and it has been realized that higher education institutions need to focus on customer centric philosophies. The concept of service quality goes beyond the technical aspects of providing the service; it includes human perception of what the services should be and how the services are to be conveyed. Several mechanisms have been adopted to assess and regularly review the quality of all aspects of education's services and suggest frameworks for service quality in education. Student satisfaction is a major driver towards adoption of a customer orientation by any organization and the higher education institution is no exception. Commensurate to this, an attempt has been made to focus on the needs of the students as primary customers and propose a framework that would help fulfill their requirements leading to satisfaction and thereby, critical service attributes and appropriate actions through student perspectives.

In order to strengthen competitiveness, a higher education institution should pay more attention to improve the most critical priority of service attributes. Thus, this paper employs an integrated model of fuzzy SERVQUAL and the refined Kano model to represent uncertain performances of the overall evaluation of the service attributes. This paper also sets out to critically improve the quality of offered critical services. In order to determine the appropriate improvements, a four actions framework of the blue ocean model is applied. The integrated model in this study reflects the student perspectives of service quality relevant to higher education.

The encountered restrictions limited the study to undergraduate programs only, thus providing no comprehensive or objective evaluations of the university's service quality overall. While this model is limited to one university and therefore not generalisable, this paper still contributes to the higher education quality management. The model generated through its application suggests that there is evidence of good practices in service quality management within the higher education sector. The evaluation does provide a university with some indicative information about its performance on its service operations. With its simplicity in concept and computation, this integrated model is of practical use for the university decision maker in identifying the priority of service attributes and determining their appropriate actions involving subjective assessments of service attributes.

The authors recommend that future research into the area of student service quality evaluation framework include other additional quantitative analysis to verify and ascertain the validity of the findings. It is argued that there is also a potential for the model developed within this paper to be applied across a broader sample of higher education institutions, both state and private universities and also within Indonesia and internationally.

\section{REFERENCES}

Benitez, J. M., Martin, J. C., and Roman, C. (2007), Using fuzzy number for measuring quality of service in the hotel industry, Tourism Management, 28(2), 544-555.

Brochado, A. (2009), Comparing alternative instruments to measure service quality in higher education, Quality Assurance in Education, 17(2), 174-190.

Brown, R. M. and Mazzarol, T. W. (2009), The importance of institutional image to student satisfaction and loyalty within higher education, Higher Education, 58(1), 81-95.

Chien, C.-J. and Tsai, H.-H. (2000), Using fuzzy numbers to evaluate perceived service quality, Fuzzy Sets and Systems, 116(2), 289-300.

Cronin, J. J. Jr. and Taylor, S. A. (1992), Measuring service quality: a reexamination and extension, Journal of Marketing, 56(3), 55-68.

De Ruyter, K., Bloemer, J., and Peeters, P. (1997), Merging service quality and service satisfaction: an empirical test of an integrative model, Journal of Economic Psychology, 18(4), 387-406.

Gapp, R. and Fisher, R. (2006), Achieving excellence through innovative approaches to student involvement in course evaluation within the tertiary education sector, Quality Assurance in Education: An International Perspective, 14(2), 156-166.

Ham, L. and Hayduk, S. (2003), Gaining competitive advantages in higher education: analyzing the gap between expectations and perceptions of service quality, International Journal of Value-Based Management, 16(3), 223-242.

Hill, Y., Lomas, L., and MacGregor, J. (2003), Students' perceptions of quality in higher education, Quality Assurance in Education, 11(1), 15-20.

Hu, Y.-C. (2009), Fuzzy multiple-criteria decision making in the determination of critical criteria for assessing service quality of travel websites, Expert Systems with Applications, 36(3), 6439-6445.

Kano, N., Seraku, N., Takahashi, F., and Tsuji, S. (1984), Attractive quality and must-be quality, Journal of the Japanese Society for Quality Control, 14(2), 147156.

Kim, W. C. and Mauborgne, R. (2005), Blue Ocean Strategy, Harvard Business School Press, Boston, MA.

Kotler, P. and Fox, K. F. A. (1985), Strategic Marketing for Educational Institutions, Prentice-Hall, Englewood Cliff, NJ.

Lee, Y.-C. and Huang, S.-Y. (2009), A new fuzzy concept approach for Kano's model, Expert Systems with Applications, 36(3), 4479-4484.

Lin, H.-T. (2010), Fuzzy application in service quality analysis: an empirical study, Expert Systems with Applications, 37(1), 517-526.

Joseph, M., Yakhou, M., and Stone, G. (2005), An educa- 
tional institution's quest for service quality: customers' perspective, Quality Assurance in Education, 13(1), 66-82.

Nasser, R. N., Khoury, B., and Abouchedid, K. (2008), University students' knowledge of services and programs in relation to satisfaction: a case study of a private university in Lebanon, Quality Assurance in Education, 16(1), 80-97.

Parasuraman, A., Zeithaml, V. A., and Berry, L. L. (1985), A conceptual model of service quality and its implications for future research, Journal of Marketing, 49(4), 41-50.

Parasuraman, A., Zeithaml, V. A., and Berry, L. L. (1988), SERVQUAL: a multi-item scale measuring consumer perceptions of service quality, Journal of Retailing, 64(1), 12-37.

Sheehan, N. T. and Vaidyanathan, G. (2009), Using a value creation compass to discover 'Blue Oceans,' Strategy and Leadership, 37(2), 13-20.
Yang, C. C. (1993), The application of two-dimensional quality model on service quality, Quality Control Monthly, 29(5), 27-33.

Yang. C. C. (2005), The refined Kano's model and its application, Total Quality Management, 16(10), 11271137.

Yang, C. C. and Yang, K. J. (2011), An integrated model of value creation based on the refined Kano's model and the blue ocean strategy, Total Quality Management and Business Excellence, 22(9), 925-940.

Yeo, R. K. (2008), Brewing service quality in higher education: characteristics of ingredients that make up the recipe, Quality Assurance in Education, 16(3), 266-286.

Zadeh, L. A. (1965), Fuzzy sets, Information and Control, 8(3), 338-353.

Zeithaml, V. A., Berry, L. L., and Parasuraman, A. (1996), The behavioral consequences of service quality, $J_{o-}$ urnal of Marketing, 60(2), 31-46. 